\title{
Terrorism and Contemporary Religious Cults: Jim Jones, Shoko Asahara and Abu Bakr Al-Baghdadi
}

\author{
Tareq S. Albhlal ${ }^{1}$ \\ ${ }^{1}$ Department of Islamic Contemporary Studies, Faculty of Science and Humanities at Rumah, Majmaah University, \\ Riyadh, Saudi Arabia \\ Correspondence: Tareq S. Albhlal, Department of Islamic Contemporary Studies, Faculty of Science and \\ Humanities at Rumah, Majmaah University, 11952, Riyadh, Saudi Arabia. Tel: 966-5-0521-7237. E-mail: \\ talbhlal@mu.edu.sa
}

Received: October 12, 2020

Accepted: November 3, 2020

Online Published: November 25, 2020

doi:10.5539/jpl.v14n1p32

URL: https://doi.org/10.5539/jpl.v14n1p32

\begin{abstract}
The present study breaks new ground in the field of radical cults as it provides a contemporary insight into three cult leaders; Jim Jones, Shoko Asahara and Abu Bakr Al-Baghdadi. This comparative analytical study will assist national and local government agencies with the identifying the relations between those leaders and their conclusions of terrorism, which in turn, had led to the mass death of cult adherents. Terrorism is a major, and growing, concern in the world today as it relates to security, safety, and the efficient operation of the most important service sectors in any state. The personalities of Jones, Asahara and Al-Baghdadi have made of them sect leaders from three very different religions: Christianity, Buddhism and Islam. Therefore, religion is not the source of radicalism/mass death as the similarities and commonalities exist among those three different groups. Eminently, this study has emphasized on the answers analytically to the research query through academic process supported by refereed articles and real-life occurrences.
\end{abstract}

Keywords: religious cults, terrorism, Jim Jones, Shoko Asahara, Abu Bakr Al-Baghdadi

\section{Introduction}

The world reeled in shock as the news broke about a mass death in November 1978 (Abbott, 2015). The mass deaths were at the hands of Jim Jones. Though not an advocate of women's rights, Jones was a radical: theologically, politically, and in racial thinking. He is remembered, however, for this collective death, in which more than 900 members of the temple died. This number included around 300 children. They died by cyanide poisoning and, that same day, five visitors to Jonestown were shot on Jones' orders whilst they stood on a runway waiting to board an aircraft to leave the town. It is well known that Jones was a religious leader whose somewhat mixed theology embraced Protestant Christianity and Communism. He established a movement that fused the central dilemmas of modern Christianity along with his followers (Hall, 2017). Hall tells an exciting tale effectively, but torn between the scientific study and the contradictory styles of docu-novel. Social scientists are in an ethical dilemma between showing sufficient private lives for permitting analysis and protecting the privacy of human subjects. Varied influential cult studies have used pseudonyms in order to sacrifice sales of their books for protecting members in a scientific publication. Various resources depicted the consequences faced by him and his group in 1960 because of rejecting capitalism and racism (Hall, 2017).

Less than a decade later, on March 20th 1995, the Japanese authorities arrested members of Aum Shinrikyo, another syncretic religious movement of recent coining (Hughes, 1998), because of their sarin gas attack on the Tokyo subway. Twelve people were killed in the attack and thousands were affected by the poisonous gas emissions. Following the atrocity, dozens of members of the group were arrested and brought to trial. The founder of the Aum Shinrikyo cult, Shoko Asahara, was convicted of masterminding the 1995 attack. He was sentenced to death in 2004. It was believed that Shoko Asahara had experienced a spiritual awakening and founded Aum Shinrikyo (meaning "religion of truth") in the 1980s (Corcoran, 2011). The cult's beliefs were a mixture of Buddhist spirituality with the instructions of the Bible. Individuals were disillusioned with Christianity and their parents became more secular after moving to the suburbs. Individuals left their birth societies or lost reachability with their original audiences and explored for more modern worship in the mid-20th century (Rodia, 2019).

However, to gain a better understanding of religion as a source of terrorism or mass death, there is a need to 
introduce the third cult leader to be discussed in this study (Rahman, 2018). A figurehead representing the supposedly Islamic-inspired vandalism of numerous ancient religious sites, Abu Bakr Al-Baghdadi was, until his death in 2019, the leader of ISIS (commonly called "Islamic State"). The events described here for which these three cult leaders were responsible have caused policy-makers to place terrorism very high up on their agendas and to become extremely sensitive to the qualitative change and dangers.

Abu Bakr Al-Baghdadi announced the formation of the Islamic State of Iraq and the Levant (ISIL) (i.e. (ISIS) translated from Arabic as the Islamic State in Iraq and Syria) on April 8th, 2013. Arguably, no other development over the past 15 years epitomizes the clash and emergence of modernity and tradition more than the rise of ISIS (Oosterveld et al., 2017). The world soon started to hear dramatic and massive developments in Al- Baghdadi's plans. Their massacring and criminal offensives included an attack on Umm al-Qura Mosque in 2011. Because of his involvement in these high-profile attacks, Abu Bakr Al-Baghdadi became an inspiring religious leader for this terrorist group (ISIL).

The inquiry of whether a religion is the source of terrorism remained moving beyond causes of mass death or terrorism, along with the part of the distortion and details of those terror crimes. These three organizations belong to three different religions: Christianity, Buddhism, and Islam. Supposedly, these three religious leaders established their own says and interpretations of the religious texts underpinning their movements and; therefore, it affected a high volume of people. It is the cultural and theological interpretation of the specific strand of religious belief that is of significant interest instead of the only evidence a group has a religious predilection. It has been claimed that the apocalyptic millenarian character ideologies are the most conducive to the quest of catastrophic destruction, in which an irremediably corrupted world must be eliminated for making way for a utopian future, and those that highlight the ability to purify from sins via sacrificial violence activities.

The present study is significant as it breaks new ground in the field of cults movement/radicalization as it provides an ethnological and analytical insight into three cult leaders; Jim Jones, Shoko Asahara and Abu Bakr Al-Baghdadi. Secondly, the terrorism is one of the most growing concerns in the world as it relates to security, safety, and among the most important service sectors in any state. It was impossible to exclude Jonestown from its social and political context. The "People Temple" and "mass death" were the terms based on the number of communes, churches, social movements, and cults, which are considered alternative for establishing social order. According to Jones, "The Temple I knew was not populated by masochists and half-wits, so it followed that the members who gave years of labour, life savings, homes, children and, in some cases, their own lives had been getting something in return" (Conroy, 2018).

The research is an attempt to answer one key question: (Is religion a source of terrorism?) and three sub-questions emerged from the main question, as follows:

1) What are the real reasons that enabled Jim Jones to attract the known large numbers of followers, and to persuade them to believe in a new religious-based existence, and to kill themselves or others by drinking poison or other ways that they did?

2) What are the real reasons that enabled Shoko Asahara to attract the known large numbers of followers, and convince them to support his religious-based movement, and to kill themselves or others by sarin gas or other ways that they did?

3) What are the real reasons that enabled Abu Bakr Al-Baghdadi to attract the known large numbers of followers, and to convince and persuade them to leave their existing way of life and embrace a new religious-based existence, and to kill themselves or others by carrying out suicide bombings or other ways that they did?

\section{Methodological Approach}

Since 2006, wider skills and interest was developed in the study of national security (Jackson-Preece, 2011). This is evident in many circumstances where Saudi Arabia encountered such terror bombers. For instance, Dowd AlShiryan, a TV presenter with MBC, made a lot of efforts to ethnographically present some of the Islamist terrorists (i.e. those people were evidently behind some of the mass death in Saudi Arabia) (Index, 2017). It has been assumed that the financial and educational reasons may not be the cause, yet the inspiration and influence of the charisma of their leaders by coming across the media interviews about those who followed the extremist ideology with an existing good education and financial backgrounds (Yusof et al., 2019; UNESCO, 2017; Helfstein, 2009). It was noticed during interactions with this information generated from such valuable interviews that they performed thoroughly on the outer face, as observed from their dress and speech. The same can exactly be said with respect to the situations faced by Jim, Asahara, and Al-Baghdadi.

Giving up autonomous identity in favour of the will of the group, aided by "institutionalized awe," which is created 
and supported by "ideology," i.e.: "investing of power in persons with particular awe-inspiring qualities, e.g. wisdom, age, spirituals, inspiration; legitimation of demands made on members by reference to a higher order principle, e.g., . . . the will of God; . . imputation of special or magical powers to members by virtue of their belonging; taking as evidence of good standing in the group the possession of magical or special powers; and linking the system to great figures of historical importance" (Kanter 1968, 514).

Notwithstanding, those followers had become radicalized by certain ideology, which is against liberal and secular values. The present study aims to discover the procedures that contribute towards this dramatic change from within three very different groups, yet with same outcome. The ethnological approach employed in this study helps in distinguishing it from other scholarly papers. By highlighting the value of ethnographic approach into mass death, it was assumed to raise awareness and interest of the subject throughout anthropology, while making an anthropological contribution to the wider aspect of suicidology. It was nonetheless observed as the engagement with sociologists as one of mutual exchange and learning instead of mere confrontation, even though it takes a critical stance towards some of the fundamental assumptions made by them. It is a fact that this study attempted to direct blind-alley discussions of cult as a whole to emphasize rather on the close social structural and relational contexts and situations throughout and under which suicidal attitudes emerge and essence elevate across diverse settings. For such reasons, this study attempted for making the volume clear and accessible for a nonanthropological readership, and assume by undertaking so to support future exchange and debate.

Therefore, Wali (2017) stated that the work of fellow researchers on this topic seemed to be characterized by their fascination for radicalization, yet from a distance. The results asserted that the major reason for this neglect has been the difficulty in collecting primary data as Islamist (i.e. radical) groups operate in a clandestine manner. This necessitates the inquiry, how can one study certain sect of terrorists or mass death groups by comparing. Building upon personal experiences, the study aimed to find out the procedures contributing towards this change.

In 2009, several field studies related to suicidal activities were initiated in the UK. This resulted in observing several processes that could lead to cult radicalization/movement, by spending several months interacting with new recruits and members e.g. the Halaqah system (private study circle) (Wali, 2011).

"The Islamic activity at that time was very different; you had very few circles and lectures. I remember attending some exhibitions. More or less anything taking place in London would be covered, for example YMO circles in Whitechapel. At that time, we started to get more people into Halaqah, and Halaqahs started to grow, then later on more people came in (Wali, 2011)".

Similarly, they were also engaged with giving consultations regarding radicalization and cult movements (Schmid, 2013). Hence, the ethnological approach will supply an insight into the inner workings of cult movements. Particularly, the cult techniques indoctrinated new members or pushed them to a mass death. Indeed, this mass death took different forms, yet the result was the same, that was mass death. In short, the approach used to acquire data from resources relied extensively on many documents, papers, and personal experiences. Some authors, specifically, on Islamic law, generally do not refer to their original resources, such as books of the four-schools. Bassiouni (1982) reported that this writing style is commonly practiced by some Islamic scholars as they assumed that those books were well known to everyone. However, these challenges are the features for this article in overcoming them and countering them; thereby, making this work distinguishable.

Some hypothetical steps have been undertaken towards comprehending wider ideas of leadership relationships and authority in terrorist organizations, but the research has a tendency for precisely focusing on two realms of investigation: (1) ethnographic researches that demonstrate the ideological and operational elements of leaders as a sub-aspect of a larger analysis, and researches on the effectiveness of leadership execution. On the one hand, promising preliminary insights were offered by the findings from the empirical case studies throughout the three selected leaders, but lack explicit investigation regarding attributes of charismatic leadership and the social dynamics encompassed in the maintenance, preparation, and dissolution of authority relationships. On the other hand, conclusive findings remain elusive because of the contradictory opinions on the overall effectiveness of the strategy, which are driven in alternative interpretations of leadership. In particular, the literature on terrorist leaders has a tendency to be emphasized on the leadership aspects and does not appropriately demonstrate why and how leaders are affective in their respective groups.

Scholarship suggests that weaker leadership creates a decentralized group. Mid-level and lower echelon members take command and attack civilians more frequently. One could argue that these organized attacks, e.g., Boston, Paris, and London, are the result of groups not having strong leadership. If a member is killed or captured, someone will fill that vacancy, regardless of their position in the rank-in-file or chain of command. Limiting or stopping all travel to certain conflict-areas around the world would prevent, or at least diminish the capabilities of lower-level 
members carrying out such horrific attacks, but I'm not sure this tactic would work for many reasons. (Christopher, 2016)

\section{Historical Analysis, Establishments, and Developments}

\subsection{Jim Jones}

Establishments and Developments:

Jim Warren Jones was born in Lynn in 1931 to an underprivileged working-class family. Since the start, Jim Jones was quiet interested in religious related activities and services for his neighborhood children. A childhood friend of Jones, Wilmore, stated that, "He was obsessed with religion; he was obsessed with death."

Jones decided to become a preacher after observing rampant racism in Indiana as he grew older. This gave him power for integrating his own church. The people from all socioeconomic and racial backgrounds were attracted by People's Temple created in Indianapolis in 1950s. Controversy was created in Indianapolis after the integration of church as the concept of Jones' multiracial congregation was not accepted by everyone. A movement was promoted in California in 1960s after harassment of Jones and his followers from outside sources. This movement was believed by Peoples Temple members to be a more progressive state, as compared to Indiana. This movement was further motivated by the growing paranoia by Jones that was concerned with the possibility of nuclear holocaust. The group headed towards west after getting confirmation that California was the safest place in United stared during the nuclear fallout. The political activity of Peoples Temple and Jim Jones was enhanced after their arrival in California, as they helped the democratic candidates to win the local elections and serve the poor and minority communities. During this time, majority of the politicians and journalists recognized the efforts of People Temple and Jim Jones.

However, in no time, the golden era for Peoples Temple ended in California. Jones set his vision of socialist utopian society in motion after undergoing several instances of bad publicity in the newspaper of San Francisco. The news was concerned with the mistreatment of his own people. The commune was in Guyana (a South American nation with Caribbean roots). Jones believed that this nation welcomes the Peoples Temple along with their unorthodox practices and beliefs. The utopian dream of Jones was comprehended with the founding of the Peoples Temple Agricultural Project; although, he was advocating or socialism and communism throughout Peoples Temple's existence. The followers of Jones successfully established themselves as a part of socialist as they moved to Guyana from California.

In this time, Jones experienced a lot of troubles, while Peoples Temple was settling in Jonestown. A complaint was also filed against Jones by Concerned Relatives, who believed that Jones was stopping people from leaving Guyana and he also abused the People Temple member's physical, emotionally, and sexually. Nothing was found amiss till Peoples Temple member Vern Gosney and others slipped the congressman notes in the upcoming days. The people wanted to leave Guyana; however, they were afraid of Jones as they believed he would not allow them to leave the place. This was the time when Jones told a visiting reporter that people were free to depart whenever they want to. Majority of the individuals from the group were not able to leave Jonestown alive as they decided to leave Jonestown with Ryan's staff. At the Port Kaitnuma airstrip, Ryan along with his entourage and defectors (as they were perceived) were trapped and fire was opened on them. In total, 5 people were killed that included Congressman Leo Ryan.

A meeting was called by Jones in the Jonestown pavilion after the shooting scenario at the airstrip. Jones prepared cyanide laced grape and entreated his people to drink that concoction and lay down their lives. Some of the people were intimidated to drink the poison after witnessing the deaths of their family and friends; however, some of them took that drink willingly. This was known as the largest mass death in the modern history as over 900 men, women, and children died in the Jonestown that day.

The religious beliefs of Jim Jones have been considered as a dichotomy throughput the time and space by majority of the historians, journalists, and scholars. During the time of 1950 and 1960, Jim Jones was considered as a traditional Pentecostal preacher; whereas, he was known as the anti-religious cult leader during 1977 and 1978 in Jonestown. He was not able to adhere to the basic tenets of Christianity; although, he called himself to be Reverend Jones.

The unorthodox methods being practiced in the church became more radical over the years as the Peoples Temple presented them as a Pentecostal church. This caused the movement of Jones towards apostolic socialism from the traditional religion. Jones headed himself as the head of the church and worthy of sole worship by his congregation, which escalated the anti-church rhetoric. It was argued that Jones cannot be considered as a preacher of Christianity and biblical teachings, rather he was responsible for creating a climate of paranoia among the People's Temple. 
Paranoid assumptions are phenomena of interest in their own right and may acclaim the understanding of delusions.

In November, 1978 Jones had started to plan the deaths of his followers, as he asked them to plan their deaths while addressing. The possibility to drink the poison of carrying out suicide bombings at Ku Klux Klan meetings was discussed by Jones and Peoples Temple during their community meeting that took place in the late 1970s. White nights were also practiced by Jones and his followers, in which they would drink beverages provided to them during the meetings. The members were instructed to consume poison after consuming the drinks. This was the time, when Jones checked the loyalty of his followers as he waited to see if they would continue drinking or not. The drinks were not poisoned. This helped Jones in gauging the reactions of his followers towards his orders. The devotion of Peoples Temple towards him would be depicted through their positive reaction to drinking the poison.

The practicing of death drills commenced by Jones started in 1976 at a Planning Commission meeting that took place before the Jonestown massacre. Cyanide was purchased by Jones and was accumulated in Georgetown (capital of Guyana) (Reiterman, 2008). The death of Jones' people was planned by him and took place in 1978. The death on Jonestown in 1978 was shocking for the members and it was difficult to accept their imminent death as it differed from the perspective of many historians and journalists.

The death of majority of Jones' congregation was reported after poisoning with cyanide-laced grape-flavoured Flavor Aid. A Few of the people were able to survive as they had escaped into the Guyanese jungles (Hall, 2017). The members present in Georgetown for basketball tournament were commanded to commit mass death by Jones. Call through the radio was also received by the Peoples Temple members in Georgetown and San Francisco to commit mass death. However, the son of Jones convinced these Peoples Temple members not to follow the instructions given by his father. Life of Amos and her children was taken slitting their throats in Georgetown.

The bodies of 900 Peoples Temples members found in Jonestown in 1978 raised many questions. This resulted in journalists and scholars to ponder on the true religion of Peoples Temple. Tom Eastham has pinpointed different pseudo-religious cults including Peoples Temple as having four fundamental attributes such as deceptive practices in recruitment; deprivation of freedom throughout the group; a very close allegiance to an individual instead of the God; and inordinate preoccupation with money for the leader, not for the charity or poor. If these qualifications were approved, the definition of Peoples Temple regarding the pseudo-religious cult was fitted. Jim Jones was called as God by Peoples Temple members and thus Jones gathered amass of money and property from his followers. The advertisement of Peoples Temple was falsely as a Pentecostal church, and Jones ignored members from leaving the Jonestown community in Guyana.

The complications with the term cult are that it has been pejoratively used by the anticult movement and sensationally by the media so that it is no longer apparent that it can be utilized as a neutral descriptive definition in social scientific investigation. In addition, it has been acclaimed that cults and sects are two different group types. Sects are divided from current organizations, such as Peoples Temple did from the Pentecostal Church while cults emerge beyond the general social environment due to a religious or spiritual development that is influential to a number of individuals. The word cult has an adverse implication even though Peoples Temple specifically comprised of cult-like aspects. The Peoples Temple was considered as a congregation among the group, for it externally resembled a Pentecostal church as compared to a cultish organization in spite of radicalism of Jones. Peoples Temple could more appropriately be considered as a New Religious Movement towards the end of the existence of the group.

\subsection{Shoko Asahara}

\section{Historical Analysis:}

Shoko Asahara founded Aum Shinrikyo in 1978, who was 40 years old legally-blind yoga teacher. He was born in 1955 in Japan to a poor family and his father made tatami (mats). His graduation was completed in 1975 from a junior college and received some informal training as an acupuncturist. This group became known worldwide for its terrorist activities among which the sarin gas attack in Tokyo subway in 1995 was the most severe (Raevskiy, 2014).

This act was surprising for the entire nation as non-military had used in human history weapons of mass destruction for the first time. This was a major shock for Japan as they were quite confident about their organized social system and there was no expectation of violence. The Japanese people did not feel safe in their own country after this cruel attack. This attack was known as an effective terrorist attack that resulted in the death of 12 people along with great psychological impact on the whole country.

It was more surprising; when it was revealed that majority of the terrorists were graduates from the famous 
universities of Kyoto, Tokyo, and Waseda. They were not uneducated misfits; rather they were qualified specialists, who were regarded as ambitious towards betterment of their country.

It is likely to consider that it was the popularity of Aum, which lead to the dramatic modifications within the organization and the tragedy in 1995. Asahara was assisted by reader, ascetic practices and intensive physical exercises for suppressing his dark side such as manipulating individuals and intentions to rule (Raevskiy, 2014). However, his powerful and larger cult became more distanced from religious practices and asked his closest disciples for performing physical exercises. Asahara became a real guru by seldom moving saying wise things, and eating his favourite food as compared to Aum whose followers had adopted extreme ascetic practices (Hudson, 2018). That allowed Asahara more extreme with his disciples by showing the first acts of violence throughout the group occurring in 1988.

It should be considered that conformist aggression comprised of several acts of aggression that are performed because of the duty for obeying orders and aggression driven by the preference to destroy (Bradshaw, 2014). Obedience is often the most inherent component in all hierarchically structured societies. Such aggression and disobedience can be observed; for instance, the Stanford prison experiment or Milgram's obedience experiments. Such experiments have revealed that individuals should not be aggressive for committing violent activities, which passively obeys orders can sometimes lead individuals to commit very extreme activities (Zinchenko, Veraksa and Leonov, 2011).

The role of Japan's defeat in the Second World War by the American soldiers should not be underestimated. This was the first time, when Hirohito narrated in his speech on radio that he was not God but an ordinary man. It was argued that this has a great psychological impact on the people. The generation of 1960 s did not consider money as their goal; rather it was just a source of providing living. Japanese religion was more complicated after the adoption of Buddhism in the 6th century (Day, 2016). The Japanese did not feel the need of spiritual functions of religion; however, American historian and religious scholar D. Metraux (2002) described the severe and hard postwar times as a "religious vacuum".

Shoko Asahara had become popular because he had understood the needs of people and used those needs in promoting his religion, effectively. He introduced levitation and supernatural abilities in the form of manga and anime, which caused the people to quickly catch the main idea (Repp, 2004). Animation and comic strips (manga) related to such topics are a progressive market. Westernization led to the progression of ideas of the superhumans and apocalypse in the society. It became a societal norm for holding interest in such ideas as these themes became dominant in society (Wessinger, 2002). This is an example of a standardized norm in society that individuals inculcated to as a pattern. The teachings of Asahara showed community as evil because of the bad karma that it amassed. Such feelings regarding the community and world facilitated her to empathize with Aum and beliefs of Asahara (Gunaratna, 2018). She understood why the society feel wrong about the Aum members they were attempting to save and; therefore, the only preference left was to destruct the society that burdened them. They could rebuild the world of Supreme Truth by forcing an Armageddon (Hoffman and Muramoto, 2007).

The people were helped in making new friends, reaching enlightenment, and developing one's skills. Asahara made sincere efforts to invite the young graduates to Aum laboratories as they were his main targets. He was a charismatic person and a talented storyteller, so he was able to make Aum an attractive cult with bright visual advertisements and a smiling, understanding guru. People were intended to leave their houses and join him after he started an active PR campaign because the students got interested in reaching spiritual enlightenment with Aum.

Establishments and Developments:

Asahara became popular among the young Japanese generation because of the social and psychological climate in the time of Aum's existence. In 1995, the increase in the popularity of Aum led to the dramatic changes inside the organization. The dark side of Asahara (his intentions to rule and manipulate people) were suppressed through intensive physical exercises and ascetic practices. Asahara distanced himself from religion and its disciplines as his cult became larger and powerful. Initially a charismatic yoga teacher, who turned out to a real guru, was violent and responsible for the violence act that occurred in 1988.

According to Asahara, every person who did wrong should be killed for his bad karma. Asahara announced that society (except Aum members) was filled with bad karma and needed power of attorney, when the Japanese did not vote for Aum in the parliamentary elections. They evolved to be the terrorists and producers of weapons that caused mass destruction. Although, it was a great surprise and shock for the Japanese; however, it was indication of the deep culture and psychology that was prevailing in Japan. Asahara used his charisma to build a successful business as religion was a popular aspect among the Japanese people at that time. It was believed that even a small religious cult led by charismatic person could achieve success because of unstable psychological climate. The sarin 
attack was committed by Asahara's disciplines; although, the consequences were suppressed by psychological illnesses.

\subsection{Abu Bakr Al-Baghdadi}

Historical Analysis:

Al-Qaeda was known as the most famous terrorist organization across the world, long before ISIS was a global household acronym. The leadership struggled to determine the best fit following the 2003 American invasion of Iraq against the American occupation in Iraq considering the other global efforts. A grisly path forward was offered by Abu Musab al-Zarqawi, who was the founder of Tawhid wal-Jihad. This group was responsible for $42 \%$ of the suicide bombings in Iraq. Zarqawi was the one who convinced Osama Bin Laden and other al-Qaeda leaders to target the Shia population. Abu Ayyub al-Masri replaced Zarqawi after he was killed in 2006 (Cronin, 2015). The merging of AQI with a broader network of Sunni fighting groups was announced by al-Masri after the death of Zarqawi. A series of administrative departments were developed by ISI under al-Masri's guidance. Baghdad was divided into six smaller sub-divisions by ISI that were governed by a local emir.

Other groups apart from al-Masri and other ISI leaders were developing its ideological principles and staffing its ranks; while, al-Masri and other ISI leaders systematically were busy in governing infrastructure of ISI. The presence of one of the largest US-run prisons in Iraq aided the efforts of ISI. Abu Bakr al-Baghdadi met and recruited majority of the future fighters of caliphate (Jefferis, 2016; Mahadevan, 2014). He was the one to demonstrate the ideological depth that drew the attention of new recruits and existing leaders alike; although, he was not an official member of organization's leadership at this time (Kolzow, 2014).

Establishments and Developments:

Al-Baghdadi joined the Shura Council of ISI in 2007 and got elected to assume the mantle of leadership after alMasri and the other heads of the organization were killed. After getting elected, he faced many challenging tasks, for instance, the demolition of leadership of al-Qaeda in Iraq by American General Odierno in 2010 (Stephan, 2015). Al-Baghdadi was commended for developing decentralized leadership structure. Therefore, he was free to distance himself even from the Bin Laden's Al-Qaeda (Jones, 2019). On the other hand, al-Baghdadi developed 'state' apparatus even that was more effective as compared to the one established by al-Masri by employing large number of former members of Saddam Hussein's military and intelligence forces (Eleftheriadou, 2020). These forces were able to advance the developments.

\subsection{The Death of the Three Cults Leaders}

According to the American Cable News Network (CNN) the leader of the Aum Shinrikyo cult Shoko Asahara whose real name is Chizuo Matsumoto was executed by hanging on July 6, 2018, at the Tokyo Detention House, 23 years after the sarin gas attack, along with six other cult members. On November 18, 1978, U.S. authorities announced the death of Jim Jones, the leader of the People Temple, who forced 918 of his followers to drink cyanide-laced "Flavor Aid" in a "revolutionary suicide" that Jones had forced them to rehearse many times before. Abu Bakr al-Baghdadi, the leader of the Islamic State (ISIS) cult, has killed himself and two children on 27 October 2019 during a raid by US commandos in north-west Syria. All activities of theses cults came to an end after the death of leaders.

\section{Commonalities between the Cults and Their Leaders}

The concepts of cult and sect is integrated into layers of understanding, which initiates from the assumption that social problem is part of the movements, which have continued to follow through the civilization. The problems result from every movement through its intensity and nature may vary, though these integrated into the heretical convictions imputations, the political curiosity, monetary irregularities, family breakups, sexual perversion, and manipulation by a controlled mind, or usage of the techniques related to brainwashing. The technical terms such as cult and sect are being viewed by the social scientist through a neutral lens, where the tension resulting from these groups is viewed from a wider society (Sopko \& Edelman, 1996).

This is done particularly in terms of the public discourse, mainly due to their avoidance of the negative implications, which these terms radiate off. Based on this, they have given rise to new religious movements (NRM) to build a façade in the form of a generic label for undergoing their research without any assumption as to whether these can be associated as the social problems or not. Though this has given rise to the debate among the sociologist, religious specialists, and historians on the term NRM and the aspects it encompasses. It is because a cult withhold by a person may be a religion of another, which requires laying down apparent boundaries which unambiguously differentiates between the two, where a defence mechanism is also established for constructing the boundary, assimilating various methods for justifying and clarifying the antagonists' different of a cult with a 'genuine 
religion'. However, various cult war has taken place through the history (Barker, 2010).

The emergence of new religions has taken place based which has resulted in clearly problematic activities. Such as, the murder of Sharon Tate and others which was done by the Manson Family in 1969. Along with it, another case of Leo Ryan and his companions, who were horrifically murdered, the mass death or murder by the Peoples Temple of Jonestown people. Following it, the Solar Temple mass death between the years 1994 and 1997, along with it, in 1995, Aum Shinrikyo members' use of the Sarin gas in the Tokyo undergone and 1997 mass death of at the heaven's gate.

Commonalities among the Cult leaders such as Jim Jones, Shoko Asahara, and Abu Bakr Al-Baghdadi was that all were apparently psychopaths, who viewed themselves as heroic and someone who can never go wrong (Ross, 2014). They termed themselves as the game changers and the idea that they were unthinkable serves as the mere foundation of their rule as well as their followers. The actions they adopted were viewed justified based on their own justification framework, which serves as the basis for their grandiose game of making the world more enlightenment, purification, and revelation as well as annihilation.

The following actions to these cult leaders were based on the followers inherent tendency and the way they interpret information which aligns with their basis, such as how the practitioner states what they want to hear, where he uses this ability to lead them away from the actual situation while at the same time, weaken their critical capacity as well as thinking ability and confidence which drives them to return to their home. The commonalities between the three leaders are that they were delusional about themselves and they deceive their followers intentionally, for their own personal benefit. It more particularly projects the idea that they are not extremists though they are extremely critically attuned and cynically egoists.

\section{Understanding the Matter of Religion and Violence}

The prime change, which is observed over the two decades in terrorism, is the exceeding number of groups as it provides religious justification for their actions and categorizing them as legitimate. It is observed that initial attention is provided to the Islamic radical movements, though; the emergence of the novel movements puts public security at jeopardy. In this regard, the incident of the Anm Shinrikyo in Tokyo can be considered where a sarin gas attack occurred in 1995. This attack posed a dangerous impression which was not only confined to its magnitude or the frightening scenario that followed it but extends to its wide-scale attempt of utilization of biological and chemical weapons by a terrorist group. This raises concern in correspondence to the violent actions these groups undertake and assess whether this is another pattern, which is integrated into the terrorist sub-category (Sopko and Edelman, 1995).

Historical records highlight that there are certain cults, which qualify the generally accepted definition of terrorist organizations, even though the phenomena integrated into it may also encompass group devoid of any political goals (Rivière, 2009). Though, it is well-established that the two dimensions of religion and politics are not mutually private. One case that fully turned towards terrorism is of Aum Shinrikyo, though, its political goals cannot be overestimated (apart from its claim of capturing the Japanese leadership) (Wilkinson, 2009). This signifies towards the classical terrorist goal, which is not only focused on intimidation for influencing the public opinion but also promotes distrust and dissatisfaction with the order that exist at the time (Change Institute for the European Commission, 2008).

Concerning the cult emotional issues, it is essential to exhibit shrewdness for carefully differentiating them and avoiding the unfair generalization. This can be observed in the previous violent cases where the alternative religious groups enhanced their understanding of the possible terrorism features. The basis of violence for each group varies and viewing them in the same perspective often misleads when the causes are being identified. The majority, the staging of the spectacular actions occurs by a small group for driving the world attention, which to a certain degree may assist them in reaching the desired goal. This can be observed in the statement made by Jim Jones, the leader of the People Temple, who declared that "We've got to go down in history. We've got to be in the history books." (Dyrendal, 2013: 122).

The attempt of making the headlines apparent served as a satisfying stimulus, which serves as a path for being acknowledged by the world, and captures their attention (Hudson, 2018). However, this does not indicate that the suicidal or murder act may merely be based on its desire to become notorious or to jolt the public or to cause a desired impact on the media constitutes, which is often perceive an important motivating force driving the actions of the secular terrorist (Wirsing and Malik, 2004). Amalgamation of other motives, the spectacular actions may though serve as a tempting choice, particularly for a group that has not achieved success or is undergoing a decline in terms of the objective, which it had hoped to achieve such as in the case of Aum Shinrikyo (Nicholls, 2007). 


\section{Conclusion}

Even though the case of Jim Jones and his Peoples Temple has been widely written about, the work fails to incorporate the radicalism which is exhibited by Jones, in the form of his political ideology, religious convictions as well as racial thinking. The research has argued upon the Jones consistent radicalism which diverges from the journalist perspective and draws the radicalisms was only apparent in the middle of the 1970 and until 1978 when the group collapsed. The perspective drawn from this study is based on the work of the existing scholar, recent sermons transcripts which are being transcribed till date, and the primary sources which California Historical Society has made available.

Moreover, various aspects of the Japanese's mentality are also important, which have been brought to light through the case of Aum and is not only confined to Japanese traditions but is inclusive of the individual general psychology. The most prime understanding gained from the sarin attack is that terrorist is not the aggressive individual who wants to perpetrate harm and violence but is driven towards practicing of the violent actions based on the calling of the certain circumstances. The followers of Aum were compelled towards religions and in acquiring salvation, who were driven towards practicing of the terrorist activities due to their strong commitment to their guru as well as group members' conformity with each other. This implies that psychological as well as social factors must also be considered when terrorism is being analyzed.

For all reasons mentioned earlier researchers are recommended to research on the charismatic leaders of terrorist movements and, for the most part, of top leaders. However future studies shall consist of primary data on ordinary members and scattered, secondary reports on leadership. For it is noticed that in the previous studies the dominance of movements by charismatic leaders is overstated in popular accounts of NRMs, few would dispute that the charismatic leader in most instances is the single most influential individual in the movement. It is also the case that NRMs often experience power struggles at the upper levels and that organizational lieutenants may exercise considerable influence, sometimes without the knowledge of the charismatic leader. This appears to have been the case for Peoples Temple movements. Particularly since dramatic movement changes and violence initiatives are likely to emanate from top leadership levels, it is imperative that social scientists place higher priority on gaining access to the halls of power.

ISISs territory control and its execution of the strict Sharia form are based on its broader religious and military network. Based on its size, there exist significant prospects of corruption in its bureaucracy, though, the continual territory loss as well as instability; these prospects amplify leading to decline in its control. The consequence that may emerge is that it may suffer a loss in terms of its characteristics, which alienates its role to local populations. ISIS follows a combination of its engagement with terrorism, and its arrangement like the state. This combination may cause its destruction including its gruesome methods, which leaves it with very few state allies though its cumbersome bureaucracy bounds.

\section{Acknowledgement}

The author is very thankful to all the associated personnel in any reference that contributed in/for the purpose of this research. The author would also like to thank Deanship of Scientific Research at Majmaah University for supporting this work under Project Number [R-1441-185]. The author additionally is thankful to the editing board and reviewers for their valuable response and fast reply that enhance the obtained results.

\section{References}

Abbott, C. B. (2015). The Reverend Jim Jones and Religious, Political, and Racial Radicalism in Peoples Temple.

Barker, E. (2010). 13 The Cult as a Social Problem. Religion and Social Problems, 198.

Bassiouni, M. C. (1982). Sources of Islamic Law, and the Protection of Human Rights in the Islamic Criminal Justice System, in The Islamic Criminal Justice System 3. London; New York: Oceana Publications.

Bradshaw, J. L. (2014). Human evolution. Psychology Press. https://doi.org/10.4324/9781315784892

Change Institute for the European Commission. (2008). Studies into Violent Radicalisation; Lot 2 The Beliefs, Ideologies and Narratives.

Christopher Bach. (2016). How Terrorism Has Affected Me? Nova Science Publishers, Inc.

CNN report. Retrieved from https://edition.cnn.com/2018/07/05/asia/japan-aum-shinriyko-leader-executedintl/index.html 
Conroy, O. (2018). An apocalyptic cult, 900 dead: remembering the Jonestown massacre, 40 years on. Retrieved from https://www.theguardian.com/world/2018/nov/17/an-apocalyptic-cult-900-dead-remembering-thejonestown-massacre-40-years-on

Corcoran, E. E. (2011). Aum Shinrikyo: Insights into How Terrorists Develop Biological and Chemical Weapons. Arms Control Today, 41(7), 7.

Cronin, A. K. (2015). ISIS is not a terrorist group: Why counterterrorism won't stop the latest jihadist threat. Foreign Aff., 94, 87.

Day, A. (Ed.). (2016). Religion and the individual: Belief, practice, identity. Routledge. https://doi.org/10.4324/9781315604848

Dyrendal, A. (2013). Violence and New Religious Movements. In J. R. Lewis (Ed.), Numen, 60(4), 473-475. Oxford: Oxford University Press. https://doi.org/10.1163/15685276-12341277

Eleftheriadou, M. (2020). Fragmentation and Cooperation in the Jihadi International (Sub) System: 'Islamic State'vs. Al-Qaeda and Beyond. Religions, 11(4), 168. https://doi.org/10.3390/rel11040168

Gunaratna, R. (2018). Aum Shinrikyo's Rise, Fall and Revival. Counter Terrorist Trends and Analyses, 10(8), 16.

Hall, J. R. (2017). Gone from the promised land: Jonestown in American cultural history. Routledge. https://doi.org/10.4324/9780203790526

Helfstein, S. (2009). The Combating Terrorism Center at West Point: Radical Islamic Ideology in Southeast Asia. Military Academy West Point NY Dept of Social Sciences and an Associate at the Combating Terrorism Center. https://doi.org/10.21236/ADA502410

Hoffman, E., \& Muramoto, S. (2007). Peak-experiences among Japanese youth. Journal of Humanistic Psychology, 47(4), 524-540. https://doi.org/10.1177/0022167806296857

Hudson, R. A. (2018). Who Becomes a Terrorist and Why? The Psychology and Sociology of Terrorism. Simon and Schuster.

Hughes, C. W. (1998). Japan's Aum Shinrikyo, the changing nature of terrorism, and the post - cold war security agenda. Global Change, Peace \& Security, 10(1), 39-60. https://doi.org/10.1080/14781159808412846

Index, G. T. (2017). Measuring and Understanding the Impact of Terrorism. Institute for Economics \& Peace.

Jackson-Preece, J. (2011). Security in international relations. University of London, p.14.

Jefferis, J. (2016). ISIS Administrative and Territorial Organization. IEMed: Mediterranean yearbook.

Jones, S. G. (2019). Beyond Baghdadi.

Kanter, R. M. (1968). Commitment and social organization: A study of commitment mechanisms in utopian communities. American sociological review, 499-517. https://doi.org/10.2307/2092438

Kolzow, D. R. (2014). Leading from within: Building organizational leadership capacity.

Mahadevan, P. (2014). The Neo-Caliphate of the "Islamic State". CSS Analyses in Security Policy, 166.

Metraux, D. A. (2002). Aum Shinrikyo and Japanese Youth.

Nicholls, S. (2007). Terrorism, millenarianism, and death: a study of Hezbollah and Aum Shinrikyo.

Oosterveld, W. T., Bloem, W., Farnham, N., Kayaoğlu, B., \& Sweijs, T. (2017). The Rise and Fall of ISIS: From Evitability to Inevitability. The Hague Centre for Strategic Studies.

Raevskiy, A. E. (2014). Psychological aspects of the Aum Shinrikyo affair. Psychology in Russia: State of the Art, 7(1), 34-39. https://doi.org/10.11621/pir.2014.0104

Rahman, T. (2018). Extreme overvalued beliefs: How violent extremist beliefs become "normalized". Behavioral Sciences, 8(1), 10. https://doi.org/10.3390/bs8010010

Reiterman, T. (2008). Raven: The untold story of the Rev. Jim Jones and his people. Penguin.

Repp, M. (2004). Aum Shinrikyo and the Aum Incident: A Critical. Controversial New Religions, 153. https://doi.org/10.1093/019515682X.003.0008

Rivière, F. (Ed.). (2009). Investing in cultural diversity and intercultural dialogue (Vol. 2). Unesco. 
Rodia, T. (2019). Is it a cult, or a new religious movement? Retrieved from https://penntoday.upenn.edu/news/itcult-or-new-religious-movement

Ross, R. A. (2014). ISIS "death cult" and "Internet brainwashing"?

Schmid, A. P. (2013). Radicalisation, de-radicalisation, counter-radicalisation: A conceptual discussion and literature review. ICCT Research Paper, 97(1), 22. https://doi.org/10.19165/2013.1.02

Sopko, J., \& Edelman, A. (1995). Global proliferation of weapons of mass destruction: A case study on the Aum Shinrikyo. Staff statement in Global Proliferation of Weapons of Mass Destruction, pp.47-102.

Stephan, M. J. (2015). Civil Resistance vs. ISIS. Journal of Resistance Studies, 1(2), 127-150.

UNESCO. (2017). Preventing Violent Extremism Through Education. A Guide for Policy-makers.

Wali, F. (2011). Radicalism unveiled: a study of Hizb ut-Tahir in Britain. Doctoral dissertation, University of London.

Wali, F. (2017). Functionality of radicalization: A case study of Hizb ut-Tahrir. Journal of Strategic Security, 10(1), 102-117. https://doi.org/10.5038/1944-0472.10.1.1525

Wessinger, C. (2002). Aum Shinrikyo and Japanese Youth.

Wilkinson, G. E. (2009). The next Aum: religious violence and new religious movements in twenty-first century Japan.

Wirsing, R., \& Malik, M. (2004). Religious Radicalism and Security in South Asia. Honolulu, HI: Asia.

Yusof, N., Kaur, A., Sani, M. A. M., \& Hashim, R. A. (2019). A qualitative expert interview approach towards understanding religious extremism among Malaysian youth. The Qualitative Report, 24(7), 1577-1592.

Zinchenko, Y. P., Veraksa, A. N., \& Leonov, S. V. (2011). Methodological foundations of military psychology and psychological security. Psychology in Russia: State of the Art, 4, 53-61. https://doi.org/10.11621/pir.2011.0004

\section{Copyrights}

Copyright for this article is retained by the author(s), with first publication rights granted to the journal.

This is an open-access article distributed under the terms and conditions of the Creative Commons Attribution license (http://creativecommons.org/licenses/by/4.0/). 